Printed
RFP-2005

UC-25 METALS, CERAMICS, AND MATERIALS

TID-4500 (59th Ed.)

URANIUM-TITANIUM ALLOYS:

\title{
ANNOTATED BIBLIOGRAPHY
}

Ross J. Jackson

\footnotetext{
This report was prepared as an account of work sponsored by the United States Government Neither sponsored United States nor the United States Atomic Energy Commission, nor any of their employees, nor any of Commission, nor any of their employees, nor any of
their contractors, subcontractors, or their employees, their contractors, subcontractors, or their employees, makes any warranty, express or implied, or assumes any legal liability or responsibility for the accuracy, completeness or usefulness of any information, apparatus,
product or process disclosed, or represents that its use would not infringe privately owned rights.
}

DOW CHEMICAL U.S.A. ROCKY FLATS DIVISION

P. O. BOX 888 GOLDEN, COLORADO 80401

Prepared under Contract AT(29-1)-1106 for the Albuquerque Operations Office U. S. Atomic Energy Commission

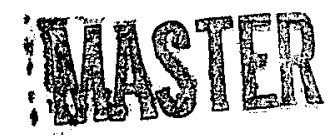




\section{DISCLAIMER}

This report was prepared as an account of work sponsored by an agency of the United States Government. Neither the United States Government nor any agency Thereof, nor any of their employees, makes any warranty, express or implied, or assumes any legal liability or responsibility for the accuracy, completeness, or usefulness of any information, apparatus, product, or process disclosed, or represents that its use would not infringe privately owned rights. Reference herein to any specific commercial product, process, or service by trade name, trademark, manufacturer, or otherwise does not necessarily constitute or imply its endorsement, recommendation, or favoring by the United States Government or any agency thereof. The views and opinions of authors expressed herein do not necessarily state or reflect those of the United States Government or any agency thereof. 


\section{DISCLAIMER}

Portions of this document may be illegible in electronic image products. Images are produced from the best available original document. 


\section{CONTENTS}

General Information; Literature and Property Surveys $\ldots \ldots \ldots \ldots \ldots$

Alloy Preparation, Processing, Fabrication, and Welding . . . . . . . . . . . . . 1

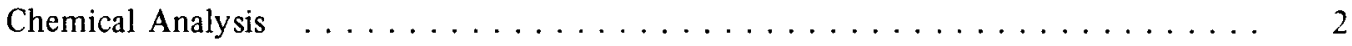

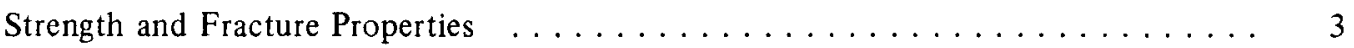

Constitutional Diagrams $\ldots \ldots \ldots \ldots \ldots \ldots \ldots \ldots \ldots \ldots$

Transformation Kinetics and Heat Treating . . . . . . . . . . . . . . . 6

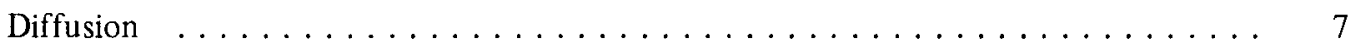

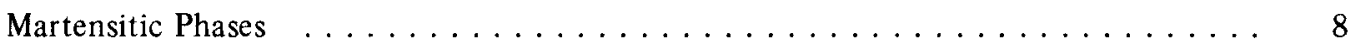

Crystallography, Deformation Modes and Textures . . . . . . . . . . . . . . 9

Microscopy and Microstructure . . . . . . . . . . . . . . . . . . . 10

Electrical, Optical, and Magnetic Properties . . . . . . . . . . . . . . . . . . 10

Thermal, Dimensional, and Thermodynamic Properties . . . . . . . . . . . . . 10

Corrosion, Oxidation, and Stress-Corrosion . . . . . . . . . . . . . . 11

Fuel Element Applications and Irradiation Effects . . . . . . . . . . . . . . . 12

Progress Reports and Newsletters . . . . . . . . . . . . . . . . . . 13

Organizational Report Symbols . . . . . . . . . . . . . . . . . . . . 15

Subject Index and Abstract Numbers . . . . . . . . . . . . . . . . . 16

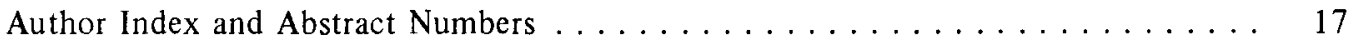


RFP-2005

\section{INTRODUCTION}

An annotated bibliography is presented for binary uranium-titanium alloys. The bibliography is complete as of January 1, 1973. Most of the references were obtained from Nuclear Science Abstracts, and to a minor extent from other sources. The accompanying resumes do not necessarily represent an entire summary of the referenced work because emphasis was placed only on that portion dealing with binary alloys of uranium containing titanium. The references have been categorized according to subject. The subject groupings are:
A. GENERAL INFORMATION AND PROPERTIES
B. ALLOY PREPARATION, PROCESSING, FABRICATION, AND WELDING
C. CHEMICAL ANALYSIS
D. STRENGTH AND FRACTURE PROPERTIES
E. CONSTITUTIONAL DIAGRAMS
F. TRANSFORMATION KINETICS AND HEAT TREATING
G. DIFFUSION
H. MARTENSITIC PHASES
I. CRYSTALLOGRAPHY, DEFORMATION MODES, AND TEXTURES
J. MICROSCOPY AND MICROSTRUCTURE
K. ELECTRICAL, OPTICAL, AND MAGNETIC PROPERTIES
L. THERMAL, DIMENSIONAL, AND THERMODYNAMIC PROPERTIES
M. CORROSION, OXIDATION, AND STRESS-CORROSION
N. FUEL ELEMENT APPLICATIONS AND IRRADIATION EFFECTS
P. PROGRESS REPORTS AND NEWSLETTERS

Within a given subject, the references are listed chronologically. Progress Reports and Newsletters (Section P) are also included in the Bibliography; however, these references are listed separately, and are categorized according to source and not subject.

In all cases, each reference is listed only once. A subject index is provided for overlapping subject matter. An index of organizational symbols and an author index are also provided. 


\title{
URANIUM-TITANIUM ALLOYS: ANNOTATED BIBLIOGRAPHY
}

\author{
Ross J. Jackson
}

A

\section{GENERAL INFORMATION; LITERATURE AND PROPERTY SURVEYS}

A 1

URANIUM-TITANIUM ALLOYS. J. R. Keeler and H. A. Saller (to U. S. Atomic Energy Commission). U. S. Patent No. 2,743,174. Apr. 24, 1956.

Binary Ti-U alloys with superior corrosion resistant properties are described. The fabrication of reactor fuel elements using these alloys is suggested.

A2

PROPERTIES OF URANIUM CONTAINING MINOR ADDITIONS OF CHROMIUM, SILICON, OR TITANIUM. H. A. Saller, F. A. Rough, and W. Chubb. Report BMI-1068. Jan. 30, 1956. Decl. with deletions Feb. 12, 1957. 28p.

Mechanical properties of a 0.5 at.\% titanium alloy were not significantly different from unalloyed uranium. Thermal conductivities and thermal-expansion properties were similar to the 0.35 at.\% chromium and 1.5 at.\% silicon alloys tested. Beta treatment of alpha-rolled stock was found to cause an increase in grain size and an increase in hardness in all alloys. Annealing the alloys at $600^{\circ} \mathrm{C}$ after beta quenching was found to soften the alloys and make the grains equiaxed without causing any change in grain size.

\section{A3}

SOME PROPERTIES OF URANIUM-LOW TITANIUM

ALLOYS. D. J. Murphy. Trans. Am. Soc. Met. 50:844-890 (1958).

A composite U-Ti constitutional diagram, summarizing data from two sources, is given. A comparison of tensile, impact, and corrosion properties between unalloyed, as-cast uranium and gamma-quenched $\mathrm{U}-0.53 \mathrm{wt} \% \mathrm{Ti}$ is also given.

\section{A4}

URANIUM METALLURGY, VOL. II: URANIUM CORROSION AND ALLOYS. W. D. Wilkinson. p. 1254-1 260. Interscience Publishers, New York. 1962.

A general summary of properties on uranium-titanium alloys is given.

\section{A5}

HEAT TREATABILITY AND PROPERTIES OF URANIUM ALLOYS. H. P. Tardif. Can. Mining Met. Bull., 68:332-342 (1965).

Density measurements, metallurgical studies, mechanical and corrosion tests, and heat treatability evaluations were made on U-base alloys containing $\mathrm{Mo}, \mathrm{Ti}, \mathrm{Zr}, \mathrm{Cb}, \mathrm{V}, \mathrm{Cr}$, $\mathrm{Mn}, \mathrm{Si}, \mathrm{Nb}, \mathrm{Ni}$, and other elements in various binary, ternary, and quaternary combinations. Tables give data on the crystallographic characteristics of $U$, the behavior of various elements in $U$, the Rockwell $C$ hardness of $U$ alloys, compression and impact properties, effects of tempering temperature on the hardness of various alloys, and tensile and bend properties. Results show that $U$ alloys are heat treatable. Binary U-2\% Mo alloys and several complex alloys have been produced with hardnesses up to Rockwell C52-57. Very slight differences in chemistry and heat treatment may affect the strength and ductility considerably. The corrosion resistance of $\mathrm{U}$ appears to be increased by the addition of small amounts of $\mathrm{Ni}$ or $\mathrm{Cr}$.

\section{A6}

METALLURGICAL STUDIES OF SOME URANIUM ALLOYS. C. Fizzotti and A. Masperoni. Energ. Nucl. (Milan), 13: 139-148 (Mar. 1966). (In Italian).

Different heat treatments such as continuous cooling, quenching and annealing, step cooling and step quenching, etc., were performed on a few uranium binary alloys and the structures obtained are described. After the heat treatments the alloys underwent thermal stability, aging tests, and thermal cycling. Corrosion and mechanical tests were also performed. The phase-diagrams of some binary systems were studied with particular regard to the uranium-rich alloys.

A7

URANIUM-LOW TITANIUM ALLOYS. Y-12 Technical Datasheet, Datasheet No. 2.2.9. Oct. 28, 1966.

Information is presented for the uranium 0.5 and $0.75 \mathrm{wt} \%$ titanium alloys. The information includes materials preparation, metal processing, toxicity, chemical purity, weldability, and machinability.

\section{B}

\section{ALLOY PREPARATION, PROCESSING, FABRICATION, AND WELDING}

B1

CASTING AND FABRICATION OF BINARY ALLOYS OF URANIUM WITH MOLYBDENUM, ALUMINUM, SILICON, TITANIUM, AND VANADIUM. R. E. Macherey and R. J. Dunworth. Report ANL-5341. June 15, 1956.

This report describes the melting, casting, and rolling to rods of binary uranium alloys containing the following 
alloying element additions: molybdenum, aluminum, silicon, titanium, and vanadium. The uraniummolybdenum alloy series included concentrations ranging from 0.05 to $6.0 \mathrm{wt} \%$ molybdenum; all other alloying element additions were below $1 \mathrm{wt} \%$. The alloys were prepared in connection with the over-all program at ANL to determine the effects of small additions of alloying elements on the growth and surface roughening of uranium resulting from thermal cycling. The thermal cycling data and some other physical properties of these alloys are described in ANL-5350.

\section{B2}

BOMB REDUCTION, FORGING AND EXTRUSION OF URANIUM AND URANIUM ALLOYS. In FUEL ELEMENT SYMPOSIUM. Paris (Nov. 18-23, 1957). Report TID-7546. Book 1. pp. 46-75(1958).

Low titanium alloys can be obtained by the co-reduction of $\mathrm{UF}_{4}$ and $\mathrm{K}_{2} \mathrm{TiF}_{4}$. A $25 \%$ excess of $\mathrm{K}_{2} \mathrm{TiF}_{4}$ gives an alloy with the desired average composition, but recasting will be necessary to eliminate excessive segregation.

B3 URANIUM MASTER ALLOYS FOR LABORATORY MELTS OF URANIUM STEELS. C. E. Makepeace. Report NP-10758. Jan. 5, 1961. $21 \mathrm{p}$.

Laboratory melts of Fe-12 wt\% U and Fe-50 wt $\% \mathrm{U}$, T.i-24 wt $\% \mathrm{U}$, and Al-12 wt $\% \mathrm{U}$, successfully used as master alloys in steel melting, were examined metallographically.

\section{B4}

PRODUCTION OF TITANIUM-URANIUM AND IRONURANIUM MASTER ALLOYS IN THE CONSUMABLEELECTRODE VACUUM-ARC FURNACE. H. V. Kinsey. Report NP-10771. Jan. 26, 1961. 13p.

High uranium alloys of titanium and iron were prepared using consumable-electrode vacuum-arc melting. Electrode and ingot production are described.

\section{B5}

\section{YIELD SURFACE OF URANIUM + .75 PERCENT} TITANIUM. E. A. Green. Report UCID-15362. July 30, 1968. 45p.

The first and fourth quadrant yield surfaces were determined for a U-Ti alloy. The effect of electron beam welding was tested by making one complete specimen from identical halves welded together by this method. The testing program revealed that the weld metal is stronger than the off-weld metal. Fracture did not start or propagate through the weld. The tentative biaxial yield surface is best described by the maximum strain criterion and is poorly described by the Mises ellipse. The material is anisotropic; in biaxial stressing where the hoop and axial stresses were equal, the axial gages indicated $0.05 \%$ off set at a lower stress than the hoop gages.

\section{C CHEMICAL ANALYSIS}

C1

ANALYSIS OF URANIUM-TITANIUM ALLOYS. G. W. C. Milner and P. J. Phennah. Report AERE-C/R1236. Sept. 23, 1953. 15p.

A satisfactory procedure is described for the determination of $\mathrm{Ti}$ and $\mathrm{U}$ in binary alloys containing from 1 to about $50 \%$ of $\mathrm{Ti}$. The primary separation of $\mathrm{Ti}$ is effected by the extraction of the cupferrate into chloroform. Traces of $\mathrm{U}$ coextracted with the $\mathrm{T} i$ in this separation are separated by using tannin and then determined absorptio-metrically via the $\mathrm{U}$ thiocyanate color complex. The major $\mathrm{U}$ content is also determined by precipitation with tannin, followed by ammonium diuranate precipitation and ignition to $\mathrm{U}_{3} \mathrm{O}_{8}$.

C2

DETERMINATION OF TITANIUM IN URANIUMTITANIUM ALLOYS BY DIFFERENTIAL ABSORPTIOMETRY. G. W. C. Milner and P. J. Phennah. Analyst 79: $414-424$ (1954) July.

The differential absorptiometric technique has proved suitable for the determination of from 5 to $75 \%$ of titanium in titanium-uranium binary alloys. The yellow color produced by titanium with hydrogen peroxide in $2.5 N$ sulfuric acid solutions was used in this work, and optical density measurements were made with both a Beckman Spectrophotometer and the Spekker absorptiometer Model H 760. Good agreement was found between the results determined with these instruments, showing that the Spekker absorptiometer has a potential use in the determination of major alloying constituents. Although macro amounts of uranium can be determined differentially, this determination proved impossible in the presence of titanium. The theoretical principles of differential absorptiometry are summarized.

C3

APPLICATIONS OF DIFFERENTIAL SPECTROPHOTOMETRY TO THE DETERMINATION OF URANIUM IN VARIOUS BINARY AND TERNARY URANIUM BASE ALLOYS. A. BAcon and G. W. C. Milner. Report AERE-C/R-1749. Sept. 20, 1955, 23p.

High-precision spectrophotometry was applied to the determination of the uranium contents of binary and ternary uranium base alloys containing zirconium, molybdenum, titanium, and niobium as alloying constituents. In most cases absorbency measurements were taken at $430 \mathrm{~m} \mu$ on solutions of the samples in $3.6 \mathrm{M}$ sulfuric acid, but for alloys containing niobium it proved necessary to make the solutions $0.2 \mathrm{M}$ in oxalic acid to prevent the hydrolysis of this element from solution. This technique has been applied to alloys with uranium contents of $40 \%$ and higher and over this range a standard deviation of $\pm 0.1 \%$ uranium was attained. Strict 
controls are necessary, however, which make this technique more suitable for the analysis of batches of samples rather than for the occasional samples.

C4

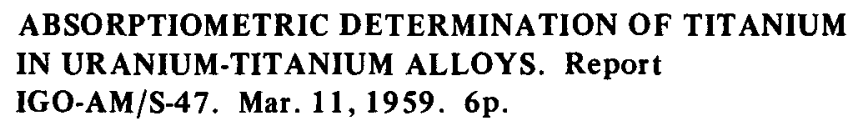

An aliquot of a nitric acid solution of the alloy is fumed with a controlled volume of sulfuric acid. Titanium is separated as the cupferrate and finally determined absorptiometrically using "Tiron" in a buffered solution. The method is applicable to titanium determinations within the range 0.05 to $0.25 \%$ in uranium-titanium alloys. Aluminum $(0.1 \%)$ is without effect, and $0.1 \%$ of iron does not interfere when reduced to the ferrous state.

\section{C5}

ANALYTICAL METHOD FOR THE ABSORPTIOMETRIC DETERMINATION OF IRON IN VARIOUS URANIUM ALLOYS. Report PG.272. 1962. 5p.

The sample is dissolved in an acid mixture. $U$ is complexed with ammonium tartrate and the iron reduced with hydroxylamine hydrochloride. The iron is determined absorptiometrically at $\mathrm{pH} 6.0$ to 6.5 using $1: 10$ phenanthroline. The method is applicable to binary alloys of $\mathrm{U}$ with $\mathrm{Mo}, \mathrm{Nb}, \mathrm{Al}$, and $\mathrm{Ti}$. At the $135 \mathrm{ppm}$ level, the standard deviation is $\pm 2.8 \%$.

\section{C6}

ANALYTICAL METHOD FOR THE SPECTROGRAPHIC DETERMINATION OF ALUMINUM IN URANIUM

ALLOYS. Report PG-390. 1964. 19p.

The sample is dissolved in acid and an aliquot is passed through an anion exchange column. The aluminum is eluted with hydrochloric acid. The aluminum is concentrated by coprecipitation on ferric hydroxide, and after dissolution in hydrochloric acid the aluminum is determined by the rotating disc electrode technique using scandium for internal standard. The method is suitable for the determination of $50-2,000 \mathrm{ppm}$ of aluminum in uranium alloys containing any one of the following elements up to the level stated: $10 \%$ iron, molybdenum, niobium, titanium, $5 \%$ chromium, $1 \%$ germanium, $0.6 \%$ silicon, $0.5 \%$ vanadium.

\section{D}

\section{STRENGTH AND FRACTURE PROPERTIES}

\section{D1}

CREEP STRENGTH OF URANIUM ALLOYS AT 1500 AND $1800^{\circ}$ F. H. A. Saller, J. T. Stacy, N. S. Eddy, and
H. L. Klebanow. Report BMI-834. May 28, 1953. Decl. Feb. 14, 1957. 36p.

The creep resistance of various $U$ binary alloys was investigated at 1500 and $1800^{\circ} \mathrm{F}$ in vacuum. Tests were made on alloys of $\mathrm{U}$ with $\mathrm{Be}, \mathrm{Nb}, \mathrm{Mo}, \mathrm{Ta}, \mathrm{Ti}$, and $\mathrm{Zr}$ and on $\mathrm{Mo}-\mathrm{UO}_{2}$ composites. Of the alloys examined, those of the U-Mo system exhibited the best creep resistance. At $1500^{\circ} \mathrm{F}$, creep rates of about $0.005 \% / \mathrm{hr}$ were produced in U-Mo alloys by a stress of $2500 \mathrm{psi}$ and, at $1800^{\circ} \mathrm{F}$, similar creep rates were obtained in composites of $90 \mathrm{wt} \%$ Mo- $10 \mathrm{wt} \% \mathrm{UO}_{2}$ by a stress of $12,000 \mathrm{psi}$.

D2

TENSILE PROPERTIES OF Ti-20U AND Ti-30U ALLOYS. H. A. Robinson, O. J. Huber, and P. D. Frost. Trans. Met. Soc. AIME 212, 485-486 (1958) Aug.

A preliminary investigation was made to determine the tensile properties attainable in two heat-treated binary titanium-uranium alloys containing 20 to $30 \%$ uranium. Both alloys responded to heat treatment, producing materials with tensile strength in the range 100,000 to 180,000 psi with adequate ductility for most structural applications. Both alloys exhibited a loss in ductility when a solution treatment at $1600^{\circ} \mathrm{F}$ preceded the aging treatment.

D3

STRENGTH AND CREEP OF URANIUM ALLOYS.

B. Boudouresques and M. Englander. p.621-631 in

"Progress in Nuclear Energy. Series V. Metallurgy and Fuels. Volume 2."

The strength and creep properties of U-Mo, U-Zr, U-Al, and $\mathrm{U}-\mathrm{Ti}$ alloys are reported.

\section{D4}

EFFECTS OF REPEATED TEMPERING ON CRACKING OF URANIUM ALLOYS. A. T. Semenchenkov and O. S. Ivanov. p.47-60 of "Stroenie i Svoistva Splavov Urana, Toriya i Tsirkoniya." Moscow, Gosatomizdat, 1963.

Repeated tempering of uranium alloys in cold and boiling water from $\gamma\left(900^{\circ}\right)$ and $\beta\left(720^{\circ}\right)$ regions resulted in $\beta$ phase retention and subsequent cracking. Cracking took place during tempering and not during the $\beta \rightarrow a^{\prime}$ transition. $\gamma$ phase tempering in oil at $200^{\circ}$ resulted in slow cooling without $\beta$ phase formation even in alloys with 0.5 at.\% $\mathrm{Cr}, 1$ at.\% Si, and 0.5 at.\% fissium. Alloying with 3 to 5 at. $\% \mathrm{Zr}, 2$ to 5 at. $\% \mathrm{Nb}$, and 3 to 5 at.\% Ti prevented cracking in alloys with 1 at.\% $\mathrm{Si}, 1$ at.\% $\mathrm{Fe}$, and 1 to 1.5 at.\% fissium.

D5

EFFECT OF ALLOY ADDITIONS AND HEAT TREAT. MENTS ON THE MECHANICAL PROPERTIES OF U-0.5 Ti ALLOY. J. I. Federer. Report ORNL-TM-2482 (1969). 
The effect of small third element additions and heat treatments on the mechanical properties of uranium- 0.5 percent titanium is considered. Aging of the U-0.5 Ti alloy for 1 hour at $400^{\circ} \mathrm{C}$ increased the tensile strength from 144,600 psi to $173,000 \mathrm{psi}$; the yield strength from 68,300 psi to 138,500 psi, and reduced the elongation from 22.8 to 18.8 percent. Aging at $200^{\circ} \mathrm{C}$ for 1 hour did not significantly change the properties, while aging for 1 hour at $600^{\circ} \mathrm{C}$ overaged the alloy causing a loss of strength and ductility. Beta quenching was detrimental to both strength and elongation.

D6

STUDY OF URANIUM-TITANIUM ALLOYS WITH LOW TITANIUM CONTENTS (0 TO 1.5 WT. PERCENT).

Report CEA-R-4180. M. Linard. Jul. 1971. $114 \mathrm{p}$. (In French). (An english translation of this report is Report ORNL-tr-2579).

The addition of small quantities of Ti improved the mechanical properties of uranium. This improvement was most significant when rapid cooling took place after the $\gamma$ phase had been reached. A relation exists between the elastic and plastic properties: the rupture and yield strengths increased uniformly with the Ti content, while the maximum elongation occurred for a Ti content between 0.4 and $0.6 \%$. After quenching in water, alloys with Ti contents greater than $0.45 \%$ presented $a_{\mathrm{a}}^{\prime}$ lamellar structures caused by martensitic transformation from the $\gamma$ phase. After quenching in oil, an $a_{\mathrm{S}}^{\prime}$ structure was produced by nucleation and growth just above the $\mathrm{M}_{\mathrm{S}}$ point. An extensive study of a $0.55 \% \mathrm{Ti}$ alloy revealed the alloy to be relatively insensitive to quenching conditions; a progressive recovery towards equilibrium conditions; interesting mechanical properties at high temperatures; and an enhanced corrosion resistance compared to the uranium alloys with low Ti contents.

D7

SOME MECHANICAL AND PHYSICAL PROPERTIES OF HEAT-TREATED ALLOYS OF URANIUM WITH SMALL ADDITIONS OF Ti OR Mo. D. J. Sandstrom. Report LA-47812. Dec. 1971. 6p.

Alloys of uranium with less than $1.5 \mathrm{wt} \%$ additions of titanium have been investigated at LASL. These alloys have been prepared from castings worked, either by hot rolling or hot extrusion, to yield a wrought structure. The alloys have been heat treated by quenching in water from the gamma region of the phase diagram to yield solution heat-treated alloys. The as-quenched material is significantly ductile and strong. After quenching, samples have been subjected to artificial aging treatments. and they seem to undergo an age-hardening reaction. A 30 to $50 \%$ increase in yield strength and increased ductility can be measured in samples that have been aged at $400^{\circ} \mathrm{C}$ for $2 \mathrm{hr}$. These materials do not appear susceptible to stress-corrosion cracking in environments of $100 \%$ relative humidity. Their general corrosion resistance is superior to that of unalloyed uranium.
D8

EFFECT OF ALLOY CONTENT, CARBON, OXYGEN, AND NITROGEN ON THE MECHANICAL PROPERTIES OF URANIUM 2.2 WEIGHT \% NIOBIUM AND URANIUM 0.75 WEIGHT \% TITANIUM WROUGHT HEAT TREATED ALlOYS. J. G. Avery. Report RFP-1950. 1973.

A series of uranium-niobium alloys was prepared with $1.8 \mathrm{wt} \%$ niobium composition and varying amounts of carbon, oxygen, and nitrogen. A similar series of uranium-titanium alloys was also prepared, with the titanium content both above and below the desired 0.75 wt\% level. The final chemical compositions of the various alloys were related to their heat-treated mechanical properties. It was found that carbon was detrimental to ductility in both uranium-niobium and uranium-titanium alloys, but did not affect the yield or ultimate strengths. In uranium-titanium alloys, variations in titanium content affected the tensile yield and ultimate strengths. In the uranium-titanium alloys, carbon levels could be reduced during melting by a reaction with titanium and subsequent gravity separation.

\section{E}

\section{CONSTITUTIONAL DIAGRAMS}

E1

TENTATIVE URANIUM-TITANIUM PHASE DIAGRAM. A. U. Seybolt, D. W. White, F. W. Boulger, and M. C. Udy. p.227-228 (of) NUCLEAR SCIENCE AND TECHNOLOGY. Vol. 1, No. 1-3, 1951 (Report TID-2502; KAPL-470).

A phase diagram for U-Ti sheet is based on a rather rough survey by thermal analysis, microscopic examination, dilatometric measurements, and $x$-ray diffraction. While many of the regions are still in considerable doubt, the major phase fields are thought to be correct on a semiquantitative basis. The compound $\mathrm{U}_{2} \mathrm{Ti}$, dividing the diagram into two parts, has a hexagonal crystal structure and melts at an estimated $2000^{\circ} \mathrm{C}$.

E2

FINAL REPORT TO THE UNITED STATES ATOMIC ENERGY COMMISSION ON THE URANIUMTITANIUM BINARY SYSTEM, by R. W. Buzzard, R. B. Liss, and D. P. Fickle. Report AECD-3418; NBS-D-112. Decl. July 8, 1952. 14p. URANIUM-TIT ANIUM BINARY SYSTEM. R. W. Buzzard, R. B. Liss, and D. P. Fickle. p. 393-399 (of) NUCLEAR SCIENCE AND TECHNOLOGY, Vol. 2, No. 1.4, 1952, (Report TID-2502). TITANIUM-URANIUM SYSTEM IN THE REGION 0 TO 30 A TOMIC PERCENT OF TITANIUM. R. W.

Buzzard, R. B. Liss, and D. P. Fickle. J. Research Nat'l. Bur. Standards 50, 209-214 (1953) Apr.

The uranium-titanium system within the range 0 to 30 atomic percent titanium was developed by thermal, 
metallographic, and $\mathrm{x}$-ray analysis. The liquidus rises from the melting point of uranium at $1130^{\circ} \mathrm{C}$ to a peritectic at $1180^{\circ} \mathrm{C}$ and $2.6 \% \mathrm{Ti}$, rising sharply to $1925^{\circ} \mathrm{C}$ at $30 \% \mathrm{Ti}$. The peritectic terminates in a sharply rising solidus at approximately $15.4 \% \mathrm{Ti}$. The system is characterized by two solid-solution (gamma and delta) phases which decompose eutectoidly. The gamma solid solution has a solubility of 8.8 percent titanium at $1180^{\circ} \mathrm{C}$ and decomposes eutectoidly at $718^{\circ} \mathrm{C}$; the eutectoid composition being 5 percent titanium. The delta solid solution decomposes eutectoidly at $830^{\circ} \mathrm{C}$, having a eutectoid composition of 18.3 percent titanium. The delta solid solution appears to be the high-melting phase rather than the compound (epsilon) as previously reported. The compound apparently forms peritectically and appeared in the extreme titanium end of the alloy range covered by this investigation.

\section{E3}

URANIUM-TITANIUM ALLOY SYSTEM. M. C. Udy and F. W. Boulger. J. Metals 200, 6, No. 2, 207-210 (1954) Feb.

A phase diagram for the binary system uranium-titanium is presented.

\section{E4}

NOTE ON THE URANIUM-TITANIUM CONSTITUTIONAL DIAGRAM. H. A. Saller and F. A. Rough. p.197-200 (of) NUCLEAR SCIENCE AND TECHNOLOGY. Vol. 4, No. 1-4, 1954, (Report TID-2505).

In the course of the preparation and study of uraniumtitanium alloys for corrosion evaluation, it became apparent that metallographic observations could not be accounted for on the basis of the current diagram of the system. As a result a brief study of the portion of the system in the vicinity of the intermediate phase was carried out. The work consisted of thermal analyses and metallographic studies. The results indicated that the intermediate phase, designated as "epsilon," was stable only to about $890^{\circ} \mathrm{C}$. Corresponding alteration of the associated two-phase regions was also indicated.

\section{E5}

THE SYSTEM URANIUM-TITANIUM. A. G. Knapton. J. Inst. Metals 83, 497-504 (1955) Aug.

The liquidus and solidus in the uranium-titanium system show a smooth increase from the melting point of uranium to that of titanium. A continuous series of solid solutions is formed between the $\gamma$ modification of uranium and the $\beta$ modification of titanium. The addition of titanium lowers the $\beta$ to $\gamma$ transformation from $771^{\circ} \mathrm{C}$ in pure uranium to a eutectoid with the intermediate $\epsilon\left(\mathrm{U}_{2} \mathrm{Ti}\right)$ phase at $723^{\circ} \mathrm{C}, 4$ at.\% titanium. Beta uranium dissolves about $1 \frac{1}{2}$ at. $\%$ titamium at the eutectoid temperature. An hexagonal phase, $\epsilon$, having the C32 structure, separates at $898^{\circ} \mathrm{C}$ from the $\gamma$ solid solution. A eutectoid is formed between $\epsilon$ and $a$ titanium at $655^{\circ} \mathrm{C}, 83$ at. \% titanium. The solubility of uranium in a titanium at the eutectoid temperature is about 0.8 at. $\%$ and the solubility of titanium in $a$ uranium is $<1$ at.\%.

E6 CONSTITUTIONAL DIAGRAMS OF URANIUM AND THORIUM ALLOYS. F. A. Rough and A. A. Bauer. p. 77-79. Addison-Wesley Publishing Co., Inc. Reading, Mass. 1958.

A brief review of the available constitutional data and crystallography on U-Ti alloys is given.

E7

ALLOY SYSTEMS URANIUM-TITANIUM, URANIUMZIRCONIUM AND URANIUM-TIT ANIUM-ZIRCONIUM. B. W. Howlett and A. G. Knapton. Report A/CONF. 15/P/1469. $21 \mathrm{p}$.

Dilatometric, metallographic, $x$-ray, and high-temperature $x$-ray methods were used in a study of the uraniumtitanium, uranium-zirconium and uranium-titaniumzirconium alloy systems. The three metals are mutually soluble in one another in their high-temperature bodycentered cubic forms, and at about $900^{\circ} \mathrm{C}$ complete solid solubility exists. There is general agreement between published versions of the uranium-titanium phase diagram, but certain aspects of the uranium-zirconium system are still controversial. A compound $(\epsilon)$ whose homogeneity range embraces the compositions $\mathrm{UZr}_{2}$ and $\mathrm{UZr}_{3}$ is present in the latter system, and the form of diagram in this region has been established. Hightemperature $x$-ray methods were used to confirm the diagram at the high-uranium end. In the ternary system, the addition of less than 1 atomic percent titanium causes the disappearance of the $\left(\gamma_{1}+\gamma_{2}\right)$ miscibility gap present in the uranium-zirconium system. Although the $\mathrm{U}_{2} \mathrm{Ti}$ compound has a narrow homogeneity range in the binary, it dissolves up to 7 atomic percent zirconium at $650^{\circ} \mathrm{C}$. The uranium-zirconium $\epsilon$ compound does not extend far into the ternary system, the solubility of titanium at $575^{\circ} \mathrm{C}$ being 3 atomic percent. No ternary compounds have been detected.

E8

EFFECTS OF ALLOYING ELEMENTS IN TITANIUM. VOLUME A. CONSTITUTION. D. J. Maykuth, H. R. Ogden, and R. I. Jaffee. Report DMIC-136A. Sept. 15, 1960. 233p.

This report surveys titanium-base phase diagrams. Constitutional data on titanium-uranium alloys are included.

E9

PHYSICAL CHEMISTRY OF ALLOYS AND REFRACTORY COMPOUNDS OF THORIUM AND URANIUM. O. S. Ivanov (Ed.). Moscow, Izdatel'stvo Nauka, 1968. 235p.

Phase diagrams and new data concerning the structure of $\mathrm{Th}$ and $\mathrm{U}$ alloys with rare metals, $\mathrm{Zr}, \mathrm{Nb}, \mathrm{Mo}$, and $\mathrm{Ti}$ are described. The results of investigating the transformations and structures of $U$ alloys in nonequilibrium states are 
reported. Information is given concerning the physical and mechanical properties and also the creep stability of $\mathbf{U}$ alloys at elevated temperatures.

\section{F}

\section{TRANSFORMATION KINETICS AND HEAT TREATING}

\section{F 1}

PROPERTIES AND HEAT TREATMENT OF URANIUMTITANIUM ALLOYS. David L. Douglass, L. Marsh, and G. K. Manning. Report BMI-1 107. July 10, 1956. Decl. Sept. 6, 1956. 40p.

The heat treatment and mechanical properties of three uranium-titanium alloys ranging in composition from 8.5 to 50 at.\% titanium were investigated. The hardness of heat-treated alloys was correlated with microstructure and $x$-ray-diffraction results. From this study the following important observations were made: (1) a direct quench of gamma uranium-titanium solid solution resulted in the formation of a hard martensitic phase in lowtitanium alloys, (2) subsequent tempering increased the hardness further by the rejection of a fine dispersion of $\mathrm{U}_{2} \mathrm{Ti},(3)$ similar hardness levels were obtained by isothermal transformation of an 8.5 at.\% titanium alloy at 400 and $500^{\circ} \mathrm{C}$, and (4) the crystal structure of the phases present at the solution-treating temperature, and the effect of temperature within a given equilibrium phase field, affected the hardness of both quenched and isothermally transformed alloys.

\section{F2}

EFFECT OF HEAT TREATMENT ON THE HARDNESS AND MICROSTRUCTURE OF U-Ti ALLOYS. D. L. Douglass and L. L. Marsh, Jr. J. Metals 9, 1260.7 (1957) Oct.

The hardness and microstructure of U-Ti alloys may be varied over wide ranges by suitable heat treatment. Quench-temper or isothermal treatments were particularly effective. The over-all response to heat treatment was dependent upon the phases present during solution treatment. Results are interpreted in terms of the phase diagram.

F3

TRANSFORMATION CHARACTERISTICS OF DILUTE TERNARY ALLOYS OF URANIUM. D. J. Murphy. A.S.M. Transactions. Preprint No. 74 (1958).

The addition to U-0.5 wt\% $\mathrm{Ti}$ base alloys of approximately 1 wt $\%$ of niobium, platinum, or molybdenum reduces the tendency of acicular martensitic alpha uranium to form at a given cooling rate, and increases the hardness of the alloy.

\section{F4}

TRANSFORMATION BEHAVIOR OF SOME DILUTE

URANIUM ALLOYS. M. D. Jepson, R. D. Kehoe, R. W. Nichols, and G. F. Slattery. Report A/CONF. 15/P/27. 25p.

Metallographic and dilatometric studies of the heat treatment behavior of technical uranium and certain alloys of interest for use in natural-uranium fuel reactors are described. The micro-structure and secondary phases present in high purity and technical purity uranium are first discussed and the time-temperature-transformation data are presented. Results on binary alloys comprising $\mathrm{U} / \mathrm{Al}, \mathrm{U} / \mathrm{Cr}, \mathrm{U} / \mathrm{Fe}, \mathrm{U} / \mathrm{Mo}, \mathrm{U} / \mathrm{Nb}, \mathrm{U} / \mathrm{Ti}, \mathrm{U} / \mathrm{V}$, and $\mathrm{U} / \mathrm{Zr}$, containing up to about 2 at.\% of the alloying element, are described. $\mathrm{Cr}, \mathrm{Fe}$, and $\mathrm{Zr}$ were found to be the most effective grain refining agents. $\mathrm{Al}$ and $\mathrm{V}$ were satisfactory under some conditions whereas $\mathrm{Mo}, \mathrm{Nb}$, and $\mathrm{Ti}$ were ineffective. The grain-size results together with the timetemperature-transformation curves indicated that grain refinement is associated with depression of the temperature of transformation on heat treatment; the extent of this depression for a given cooling rate being dependent on the alloy content. In practice it was found that alloys such as $\mathrm{U} / \mathrm{Zr}$ and $\mathrm{U} / \mathrm{Fe}$ responded to water quenching treatments, and optimum refinement of others (e.g., $\mathrm{U} / \mathrm{Cr}$ ) resulted from isothermal treatment at 500 to $600^{\circ} \mathrm{C}$.

F 5

ALLOYING EFFECTS ON URANIUM $\beta$ PHASE DURING TEMPERING. A. T. Semenchenkov and O. S. Ivanov. p. 22-36 of "Stroenie i Svoistva Splavov Urana, Toriya i Tsirkoniya." Moscow, Gosatomizdat. 1963.

Effects of alloying with $\mathrm{Al}, \mathrm{Be}, \mathrm{Fe}, \mathrm{Mo}, \mathrm{Nb}, \mathrm{Ni}, \mathrm{Si}, \mathrm{Th}$, $\mathrm{Ti}, \mathrm{Zr}$, and fissium on $\beta$ phase uranium at $\gamma\left(900^{\circ}\right)$ and $\beta$ $\left(720^{\circ}\right)$ tempering were studied. Uranium alloyed with $\mathrm{Al}, \mathrm{Si}, \mathrm{Fe}, \mathrm{Ni}, \mathrm{Nb}$, and fissium retains its $\beta$ phase down to room temperature during cold water tempering, whereas $\mathrm{U}$ alloyed with 0.5 to 15 at. $\% \mathrm{Be}, 0.5$ to 5 at.\% $\mathrm{Ti}, 0.4$ to 30 at.\% $\mathrm{Zr}$, and 0.1 to 3.0 at.\% Th do not retain the $\beta$ phase at room temperature, but have an $a^{\prime}$ solid solution structure. Increased alloying with $\mathrm{Zr}$, $\mathrm{Nb}, \mathrm{Ti}$, and Mo inhibit the $\beta$ stabilizing effects of $\mathrm{Si}, \mathrm{Fe}$, and fissium.

F6

INFLUENCE OF THE RATE OF COOLING FROM THE $\gamma$ PHASE ON THE STRUCTURES OF URANIUMRICH ALLOYS CONTAINING TITANIUM. C. Fizzotti and G. Franceschetti. Report RT/MET (64)-3. Aug. 1964. $26 \mathrm{p}$

The influence of the cooling rate from the $\gamma$ phase on the structure of uranium alloys containing up to $1.5 \mathrm{wt} \%$ titanium was investigated. Low cooling rates yielded fine dispersion of $\mathrm{U}_{2} \mathrm{Ti}$ in the $a$ matrix, while at high cooling rates fine lamellae were obtained. Water quenching caused the complete retention of titanium in solid solution yielding martensitic structures. The grains of 
the $a$ matrix were progressively refined by increasing the cooling rates.

F7

\section{PRECIPITATION HARDENING OF URANIUM-} TITANIUM ALLOYS CONTAINING LESS THAN 1.0 WEIGHT PERCENT TITANIUM. A. M. Ammons. Report Y-1850. Sept. 25, 1972.

Strengthening mechanisms in U-Ti alloys containing less than 1.0 weight percent titanium were determined. Gamma quenching of the U-0.5 wt $\% \mathrm{Ti}$ alloy produced a strong ductile material with a yield strength of $79.4 \mathrm{ksi}$ and 26 percent elongation. Subsequent aging of $\gamma$ quenched alloy produces an increase in hardness and yield strength with a decrease in ductility. The $b$ parameter continues to contract up to 72 hours at $400^{\circ} \mathrm{C}$ indicating a further clustering of the titanium atoms; i.e., G. P. zone information. After aging for 6 hours at $400^{\circ} \mathrm{C}$, small zones of $\mathrm{U}_{2} \mathrm{Ti} 25$ to $40 \AA$ in diameter were observed in the microstructure with transmission electron microscopy. Aging for 72 hours at $400^{\circ} \mathrm{C}$ produced a maximum hardness of $511 \mathrm{DPH}$ and a maximum strength of $145.2 \mathrm{ksi}$. The transmission electron microstructure showed a basket-weave structure caused by the overlap of the strain fields associated with the $\mathrm{U}_{2} \mathrm{Ti}$ precipitate. Stereographic analysis indicates the habit plane of the precipitates is the $(010)$ of $a-$ uranium. The orientation relationship between the precipitate and matrix is $(01 \overline{1} 0) \mathrm{U}_{2} \mathrm{~T} i l l(010) a-\mathrm{U}$ with

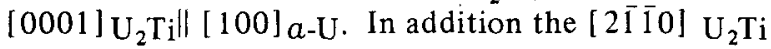
\| [001] $a-\mathrm{U}$. Continued aging past maximum hardness, produces growth of the precipitates particularly at grain boundaries. The optical metallography shows a two-phase structure with the grain boundaries being equilibrium $a$ plus $\mathrm{U}_{2} \mathrm{Ti}$ while the center of the grains are untransformed $a_{\mathrm{a}}^{\prime}$. The transformation at long aging times proceeds along the martensitic platelets and produces precipitates less than 2 microns in diameter after 240 hours at $600^{\circ} \mathrm{C}$

\section{G DIFFUSION}

\section{G 1}

\section{DIFFUSION OF URANIUM WITH VARIOUS} TRANSITIONAL METALS. Y. Adda and J. Philibert. Report A/CONF. 15/P/1160. 38p.

The diffusion process in uranium and its alloys was studied from 550 to $1075^{\circ} \mathrm{C}$ with diffusion couples of $\mathrm{U}$ with $\mathrm{Zr}, \mathrm{Mo}, \mathrm{Ti}$, and $\mathrm{Nb}$ and with the alloys $\mathrm{U}-\mathrm{Nb}$ and U-Mo. A brief description is given of the experimental methods. Results relative to the concentrationpenetration curves are presented, and the coefficients of diffusion are calculated. The equilibrium diagram was established for the U-Zr system. The results obtained by micrographic examination, microhardness measurements, and autoradiography are compared with one another. The mechanisms of diffusion are investigated by studying the Kirkendall effect and calculating the Darken intrinsic coefficients in the U-Zr and U-Mo diffusion couples.

G2

DETERMINATION OF DIFFUSION COEFFICIENTS AND STUDY OF THE KIRKENDALL EFFECT ON THE URANIUM-TIT ANIUM COUPLE. Y. Adda and J. Philibert. Compt. rend. 247, 80-83 (1958) July 7. (In French)

The concentration-penetration curves were established for the Ti-U diffusion couple between 950 and $1075^{\circ} \mathrm{C}$. The coefficient of chemical diffusion was determined as a function of the concentration. The Kirkendall effect was studied quantitatively, and the coefficients of intrinsic diffusion were calculated for uranium and titanium.

G3

DIFFUSION IN THE SYSTEM URANIUM-TITANIUM. Y. Adda and J. Philibert. Acta Met. 8, 700-710 (1960) Oct. (In French).

The intermetallic diffusion in Ti-U alloys is studied at 650 to $1050^{\circ} \mathrm{C}$ by metallography, microhard ness, and the Castaing microanalyzer. The diffusion coefficient, the frequency factors, and the activation energies were determined in the $\gamma$ phase (centered cubic) for uranium concentrations of 0.05 to 0.9 . An important Kirkendall effect was in evidence and the intrinsic diffusion coefficients of uranium and titanium were calculated on the basis of Darken's relations. The results compared to those previously obtained for $\mathrm{Zr}-\mathrm{U}$ alloys, show that the mobility of titanium atoms is higher than that of zirconium atoms. Furthermore, the supersaturation vacancies from the Kirkendall effect was evaluated to explain the difference in porosity observed in the couples $\mathrm{U}-\mathrm{Zr}$ and Ti-U. Values of $\sim 10^{-3}$ were found for the two couples. It is concluded that the difference in porosity is caused by different conditions of nucleation.

\section{G4}

DETERMINATION OF EQUILIBRIUM DIAGRAMS BY DIFFUSION IN THE SOLID STATE. Y.Adda, $M$.

Beyeler, A. Kirianenko, and F. Maurice. Mem. sci. rev. mét., 58: 716-724 (Sept. 1961). (In French). (A translation of this is Report HW-tr-37).

Diffusion tests in the solid state are carried out for various binary systems: U-Ti, U-Ni, Al-Ni and others in a temperature range where several phases coexist. Some of the equilibrium diagrams are derived from concentration/penetration curves established by the electronic-probe microanalyzer. The advantages and drawbacks of this method are described and an attempt is made to explain the differences between the equilibrium diagrams determined by conventional methods and those determined by solid-state diffusion. 
G5

COMPATIBILITY OF FISSIONABLE MATERIALS WITH CONSTRUCTION MATERIALS. PART 1. COMPATIBILITY OF METALLIC FISSIONABLE MATERIALS WITH CLADDING MATERIALS. HeinzEberhard Roellig. Report ZFK-WF-13. Mar. 1962.

91p. (In German).

The compatibility of uranium, plutonium, and thorium with aluminum, zirconium, magnesium, beryllium, titanium, ferrous metals, and refractory metals is summarized. Preparation of samples and assemblies, annealing procedure, and examination of reaction zones are described. Results of the different investigators (diffusion and penetration coefficients, activation energies, etc.) are analyzed and discussed.

\section{G6} CONTRIBUTION TO THE COMPATIBILITY OF URANIUM-TITANIUM SYSTEM. M. Holinka, V. Masarik, and E. Karnikova. Jarderna Energie, 9: 109. 113 (1963). (In Czechoslovakian).

Qualitative metallographic investigations of uranium and titanium diffusion with regard to $\mathrm{UO}_{2}$ phase forming and behavior are described. A review of foreign literature concerning the U-Ti system is given, the experimental method used for material compatibility investigation is described, and the results and method of qualitative evaluation of diffusion progress are reported.

G7

DIFFUSION OF PLUTONIUM IN SOLID STATE. D. Calais, J. A. Cornet, J. F. Cornet, J. A. Languille, and C. Rémy. In W. N. Miner, Ed., PLUTONIUM 1970 AND OTHER ACTINIDES, Part 1, AIME, New York, 1970. (p. 135-143). (This study is also reported in Report CEA-CONF-1635).

This report deals primarily with plutonium alloys; however, it is mentioned that in Ti-U alloys, an accelerated diffusion of the solute atoms occurs during the martensitic $\beta \rightarrow a$ transformation.

H

MARTENSITIC PHASES

H1

TRANSFORMATIONS IN URANIUM ALLOYS WITH HIGH SOLUTE SOLUBILITY IN THE B.C.C. GAMMA PHASE. PART I. PRELIMINARY OBSERVATIONS ON THE "BANDED STRUCTURES" PRODUCED BY NON EQUILIBRIUM TRANSFORMATIONS IN URANIUM ALLOYS. A. G. Harding and M. B. Waldron. Report AERE-M/R-2673. Sept. 1958. 34p.
The high-temperature body-centered cubic $\gamma$ phase in uranium alloys with approximately 10 at. $\%$ titanium, niobium, zirconium, or molybdenum can be rendered metastable under critical cooling conditions; it may transform thence by a shear mechanism to form a characteristic banded structure or by a nucleation and growth process to equiaxed grains. These decomposition structures with differing metallographic appearances give similar $\mathrm{x}$-ray patterns. The structures are designated "distorted $a$ " since the patterns correspond to a contraction in the b-direction of the normal orthorhombic $a$ cell. The formation of these metastable structures is apparently dependent upon composition, cooling rate, and the effect of the solute element on the incubation period, and the decomposition rate of the metastable $\gamma$ phase.

\section{$\mathrm{H} 2$}

TRANSFORMATIONS IN URANIUM ALLOYS WITH HIGH SOLUTE SOLUBILITY IN THE GAMMA PHASE, PART II: TRANSFORMATION IN URANIUM ALLOYS OF 5, 10, 15, AND 20 at.\% TITANIUM ON QUENCHING FROM THE GAMMA PHASE. A. G. Harding, M. B. Waldron, and C. Knight. Report AERE-M/R-2673A (1958).

The b.c.c. $\gamma$ phase of the system uranium-titanium when rendered metastable by quenching, may decompose to one of three metastable phases: on mercury quenching at 10 at.\% titanium by a shear transformation to $a_{\mathrm{s}}$ and at 15 at.\% titanium to a phase exhibiting some degree of anisotropy designed $\gamma^{0}$; or at the slower cooling rates at $\sim 1$ in. from the quenched tip of mercury and quenched specimens to a distorted $a$ structure $a_{\mathrm{n}}^{\prime}$, by nucleation and growth. On mercury quenching a 20 at.\% titanium alloy a metastable $\gamma$ phase may be retained at room temperature. The marked hardness changes of 150 V.P.N. -650 V.P.N. developed along the end quenched rods is due apparently to dispersion hardening associated with $\mathrm{U}_{2} \mathrm{Ti}$ precipitation from the supersaturated metastable phases.

\section{H3}

STRUCTURE AND MECHANICAL PROPERTIES OF URANIUM-TITANIUM MARTENSITES. D. L. Douglass. Trans. Am. Soc. Metals, 53: 307-319 (1961).

Small amounts of titanium were very effective in increasing the strength of martensitic uranium. The strengthening effect saturated at about 2 at.\% $\mathrm{Ti}$ and was not due to the presence of a second phase. Lattice parameter changes with composition were continuous both $\mathrm{a}_{\mathrm{O}}$ and $\mathrm{c}_{\mathrm{O}}$ increased with increasing solute, whereas $\mathrm{b}_{\mathrm{o}}$ decreased. The measured changes were greater than those calculated on the basis of size differences alone. Severe broadening of the $\mathrm{x}$-ray-diffraction lines indicated the presence of non-uniform microstresses. The volume strain which occurred during the transformation of $\gamma \rightarrow a^{\prime}$ at the $\mathrm{M}_{\mathrm{S}}$ temperature decreased at approximately 2 at.\% Ti. It is suggested that the hydrostatic pressure 
caused during transformation decreased at this composition and was less than the yield point in alloys containing more than 2 at.\% $\mathrm{Ti}$. Tangential stresses existed at the surface as the outer portion of each sample transformed prior to the interior. Both stresses were sufficient to cause plastic deformation as evidenced by twins in the martensite and sample distortion.

\section{H4}

METASTABLE PHASES IN URANIUM-TITANIUM

ALLOYS. M. Anagnostidis, R. Baschwitz, and M. Colombie. Mem. Sci. Rev. Met., 63: 163-168 (Feb. 1966) (In French).

A study was made on the regions in which metastable phases exist in U-Ti, U-Mo, and U-Nb alloys. The behavior of titanium seemed to be different from that of molybdenum and niobium; this could possibly be explained by the relative position of these elements in the periodic table or by different relationships between uranium and titanium.

\section{H5}

\section{STUDY ON THE RETURN FROM THE ORTHORHOMBIC METASTABLE PHASES OF URANIUM-TITANIUM ALLOYS CONTAINING 4.8 AND 9.5 PERCENT} TITANIUM. R. Baschwitz, M. Colombie, and M. Foure. J. Nucl, Mater., 28: 245-256 (1968). (In French). (A transulation of this study is Report ORNL-tr-2440.)

Annealing of metastable phases, obtained by quenching from the gamma domain U-Ti alloys containing between 4.8 and 9.5 at.\% of titanium, was studied by micrography, hardness measurement, microhardness measurement, and by x-ray diffraction; with a view to comparing the behavior of these alloys with that of U-Mo and U-Nb alloys. In contrast with the behavior of U-Mo and $\mathrm{U}-\mathrm{Nb}$ alloys, the annealing behavior of $a_{\mathrm{a}}^{\prime}$ and $a_{\mathrm{b}}^{\prime}$ phases of the U-Ti alloys are qualitatively identical; the banded phases in the U-Ti alloys do not give rise to the precipitation of an equilibrium phase. For structures in the system U-Ti, a classical process of precipitation-hardening is observed, followed by direct precipitation of the stable compound. This important difference from U-Mo and U-Nb alloys is taken to be caused by the presence of the intermetallic compound $\mathrm{U}_{2} \mathrm{Ti}$. A consequence of this is that the $a_{\mathrm{b}}^{\prime}$ phase richer in titanium produces a very high hardness maximum which is distinctly higher than that associated with acicular structures with a smaller solute content. Recrystallization was observed during the 4 th stage of annealing of these alloys, which appears to be related to the second recrystallization observed in U-Mo alloys with a banded structure. It was not possible to confirm the phenomenon of solution and reprecipitation of the second phase at the transformation front. On the contrary, it seems that the precipitates of $\mathrm{U}_{2} \mathrm{Ti}$ are related in orientation to the original gamma structure and not with the new alpha structure.

\section{1 \\ CRYSTALLOGRAPHY, DEFORMATION MODES AND TEXTURES}

I1

CRYSTAL STRUCTURE OF TiU 2 . A. G. Knapton. Acta Cryst. 7, 457-458 (1954) May 20.

$\mathrm{TiU}_{2}$ was found to be a layer-type structure with alternate planes of $\mathrm{Ti}$ and $\mathrm{U}$ atoms normal to the $c$ axis. Each $\mathrm{T} i$ atom is surrounded by twelve $\mathrm{U}$ atoms, six in the layer above and six in the layer below, at a distance of $3.14 \AA$ and two Ti atoms at $2.85 \AA$. Each $U$ atom is surrounded in the $U$ plane by an equilateral triangle of three $U$ atoms at $2.80 \AA$ and by two $U$ atoms, one in the plane above and one below at $2.85 \AA$.

\section{2}

NEW DATA ON THE STRUCTURE OF BiIn 2 AND THE POSSIBLE STRUCTURE OF TIBi ${ }_{1 \cdot 27 \rightarrow 1} \cdot 59, \mathrm{NaHg}_{2}$, $\mathrm{UHg}_{2}, \mathrm{UZr}_{2}$, AND TiU ${ }_{2}$. Ye. S. Makarov. Kristallografiay 3, No. 1, 5-9 (1958).

The crystal structure of $\mathrm{BiIn}_{2}, \mathrm{TlBi}_{1.27 \rightarrow 1.59}, \mathrm{NaHg}_{2}$, $\mathrm{UHg}_{2}, \mathrm{UZr}_{2}$, and $\mathrm{TiU}_{2}$ was studied by $\mathrm{x}$-ray diffraction of their powders. The results showed that $\mathrm{BiIn}_{2}$ has a structure of the $\mathrm{Ni}_{2}$ In type with the lattice constants $a=5.496 \pm 0.001, c=6.579 \pm 0.001$, and $c / a=1.197$. It is suggested that the other metals studied have an analogous structure. $\mathrm{BiIn}_{2}$ differs from other compounds of the $\mathrm{Ni}_{2} \mathrm{In}$ type by having a lower axial ratio and by the exclusion of a transition metal. The axial ratios for the other compounds studied were found to be 0.59 for $\mathrm{TiU}_{2}, 0.61$ for $\mathrm{UZr}_{2}, 0.64$ for $\mathrm{UHg}_{2}$, and 0.64 for $\mathrm{NaHg}_{2}$.

\section{3}

ISOTHERMAL DECOMPOSITION OF GAMMAPHASE URANIUM-TITANIUM ALLOYS. R. D. Tomlinson, J. M. Silcock, and J. Burke. J. Inst. Metals; 98: 154-160 (May 1970).

The isothermal decomposition of the $\gamma$ phase in U-Ti alloys containing 15,20 , and 25 at. $\%$ Ti was studied by single-crystal and polycrystalline $x$-ray methods, together with metallographic observations and microhardness measurements. A limited investigation of the process using electrical resistivity measurements was also made. The single-crystal $\mathrm{x}$-ray work indicates that the $25 \% \mathrm{Ti}$ alloy decomposes during quenching from $1475^{\circ} \mathrm{K}$ to room temperature into a coherent hexagonal phase closely related to $\mathrm{U}_{2} \mathrm{Ti}$ with [0001] hex $\|[111] \gamma$ and $[2 \overline{1} \overline{1} 0]_{\text {hex }} \|[1 \overline{1} 0] \gamma$. In polycrystalline specimens the continuous precipitation within the grains is accompanied by a grain-boundary-nucleated discontinuous reaction to $a+\mathrm{U}_{2} \mathrm{Ti}$. Both the nucleation and growth of the discontinuous reaction are very sensitive to the matrix orientation. Matrix hardening and overaging is attributed to the rapid formation of the hexagonal phase followed by the precipitation of $a$-uranium. 


\section{$J$ MICROSCOPY AND MICROSTRUCTURE}

J1 URANIUM ALLOY DEVELOPMENT, PART IV. A. U. Seybolt. Report LA-68 (1944).

A photomicrograph of a $\mathrm{U}-1.5$ at.\% $\mathrm{Ti}$ alloy is shown. Some hardness data are presented.

\section{J2}

NOTES FROM THE SECOND METALLOGRAPHY CONFERENCE AT BATTELLE MEMORIAL INSTITUTE ON JANUARY 11, 1950. H. A. Saller and R. F. Dickerson. Report AECU-1235. Jan. 11, 1950. 12p.

The metallographic techniques used by various laboratories to prepare and examine $\mathrm{Ti}, \mathrm{Zr}, \mathrm{Be}$, and $\mathrm{V}$ metals and $\mathrm{Ti}-\mathrm{U}$ alloys are discussed briefly. Grinding and polishing techniques and compositions of etchants and electroly tic baths are outlined.

\section{K \\ ELECTRICAL, OPTICAL, AND MAGNETIC PROPERTIES}

No information was found, on these properties, in the available literature.

\section{L}

THERMAL, DIMENSIONAL, AND THERMODYNAMIC PROPERTIES

\section{L1}

MEMORANDUM ON URANIUM TITANIUM ALLOYS. L. L. Wyman. Report KAPL-M-LLW-1. Sept. 19, 1949. 4 p.

A series of four U-Ti alloys containing 15, 26.4, 35, and $45 \mathrm{wt} \% \mathrm{Ti}$ were run in the precision differential dilatometer. With the possible exception of the high temperature transformation in the $15 \% \mathrm{Ti}$ alloy, all the changes took place over an appreciable range of temperature.

L2

DIMENSIONAL STABILITY OF SOME BINARY URANIUM ALLOYS UNDER THERMAL CYCLING. S. T. Zegler. P. 254-263 [of] PROCEEDINGS OF THE METALLURGY AND MATERIALS INFORMATION MEETING, APRIL 16-18, 1951, HELD AT OAK RIDGE, TENNESSEE, SPONSORED BY OAK RIDGE NATIONAL LABORATORY. Report TID-5061 (Del.) VOLUME I.
Alloying $U$ with small amounts of a suitable element to refine grain size on $\beta$-treating has appeared for some time as a possible means of obtaining optimum dimensional stability on thermal cycling. The stability of several arbitrarily selected alloys was investigated to explore this possibility. Binary alloys with $\mathrm{Z}_{\mathrm{r}}, \mathrm{Mo}, \mathrm{Ti}$, $\mathrm{V}, \mathrm{Si}$, and $\mathrm{Al}$ were selected. Preparation involved rolling from castings to $1 / 2$-in.-diam. rounds at $600^{\circ} \mathrm{C}$, the first four alloy series to $89 \%$ R.A. and the $\mathrm{Si}$ and Al alloys to $75 \%$ R.A. Specimens, 0.364 in. in diam. by approximately $1.5 \mathrm{in}$. long, as machined and centerless ground, were used in cycling. Cycling was done between 100 and $500^{\circ} \mathrm{C}$ with a $5-$ to $7-\mathrm{min}$. heating time and a 20 to $25 \mathrm{~min}$. cooling time in the induction heating unit at ANL.

\section{L3}

EFFECTS OF THERMAL CYCLING ON CREEP AND STABILITY OF $a$ PHASE BINARY ALLOYS OF URANIUM WITH TITANIUM, AND CHROMIUM. N. E. Sladkova and V. K. Grigorovich. p. 162.168 of "Stroenie i Svoistva Splavov Urana, Toriya i Tsirkoniya." Moscow, Gosatomizdat, 1963.

Effects of cyclic heating on the dimensional and structural stability of $a$ phase binary uranium alloys with $\mathrm{Cr}, \mathrm{Ti}$, and $\mathrm{V}$ were studied. The results of chemical analyses of U-Ti and U-V alloys were tabulated, and diagrams were constructed of the creep rate, deformation, and expansion of alloys exposed to 500 to 2000 thermal cycles $\left(600 \rightleftarrows 35^{\circ} \mathrm{C}\right)$.

L4

THERMODYNAMICS OF PLUTONIUM, THORIUM AND URANIUM METALLIC SYSTEMS. I. Johnson. P. 171-192 of [ "Nuclear Metallurgy. Vol. X. Symposium on Compounds of Interest in Nuclear Reactor Technology." New York, A.I.M.E., 1964.]

The available thermodynamic data for metallic systems of thorium, plutonium, and uranium are reviewed. Data for the following systems are given: plutonium with $\mathrm{Al}$, $\mathrm{Be}, \mathrm{Cd}, \mathrm{Ce}, \mathrm{Cu}, \mathrm{La}, \mathrm{Pb}, \mathrm{Fe}, \mathrm{Mg}, \mathrm{Ru}, \mathrm{Ag}, \mathrm{Ti}, \mathrm{U}, \mathrm{Zn}$, and $\mathrm{Zr}$; thorium with $\mathrm{Al}, \mathrm{Bi}, \mathrm{Mg}, \mathrm{Hg}$, and $\mathrm{Zn}$; and uranium with $\mathrm{Ag}, \mathrm{Al}, \mathrm{Au}, \mathrm{Be}, \mathrm{Bi}, \mathrm{Cd}, \mathrm{Fe}, \mathrm{Ga}, \mathrm{Ge}, \mathrm{Hg}, \mathrm{In}, \mathrm{Mg}$, $\mathrm{Pb}, \mathrm{Si}, \mathrm{Sn}, \mathrm{Tl}$, and $\mathrm{Zn}$. A new method for the estimation of the entropy of formation of intermetallic compounds is given.

\section{L5}

INVESTIGATION OF THE QUASI-LOCAL LEVEL IN THE VIBRATIONAL SPECTRUM OF THE Ti LATTICE WITH HEAVY IMPURITY ATOMS. N. A. Chernoplekov, G. Kh. Panova, M. G. Zemlyanov, B. N. Samoilov, and V. I. Kutaitsev. Phys. Status Solidi, 20: $767-770$ (Apr. 1, 1967).

A quasi-local level appears in the vibrational spectrum of $\mathrm{Ti}$ lattices containing 5 at.\% $\mathrm{U}$. This is investigated by neutron in-elastic scattering techniques and by measuring the low-temperature heat capacity. The results obtained are found to be in satisfactory agreement with theoretical calculation. 
L6

EXPERIMENTAL DETECTION OF AN ANOMALY IN THE SPECIFIC HEAT OF A METAL WITH NONMAGNETIC HEAVY IMPURITY ATOMS. G. Kh. Panova, and B. N. Samoilov. p. 191-5 of Proceedings of the First International Conference on Calorimetry and Thermodynamics. Warsaw: Polish Scientific Publishers (1969).

Studies were made on the quasi-local level in the vibrational spectrum of the lattice of alloys with heavy impurity atoms by measuring the low-temperature heat capacity. Data are given on the quasi-local level in the vibrational spectrum of the Ti lattice with an admixture of 5 at.\% U. A plot of the relative heat capacity change against $\mathrm{T}$ over the range 1.2 to $20^{\circ} \mathrm{K}$ indicated the existence of a pronounced anomaly in the heat capacity of $\mathrm{TiU}$ at $12^{\circ} \mathrm{K}$. The heat capacity of the TiU alloy was 2.7 times that of pure $\mathrm{Ti}$ at the maximum. The results confirmed the theoretically predicted strong deformation of the low frequency part of the phonon spectrum in the crystals associated with introduction of heavy impurity atoms and may serve as indirect proof of the existence of quasi-local frequencies in TiU alloys.

M

\section{CORROSION, OXIDATION, AND STRESS-CORROSION}

\section{1}

AQUEOUS CORROSION OF URANIUM AND ALLOYS: SURVEY OF PROJECT LITERATURE. J. W. McWhirter and J. E. Draley. Report ANL-4862. 1952.

As-cast uranium-titanium alloys containing 7.2 to 9.5 wt $\%$ of titanium in water at $100^{\circ} \mathrm{C}$ have a weight-loss rate of less than $0.001 \mathrm{mg} / \mathrm{cm}^{2}-\mathrm{hr}$. At $178^{\circ} \mathrm{C}$ the rate is $5.9 \mathrm{mg} / \mathrm{cm}^{2}-\mathrm{hr}$. In a $500-\mathrm{hr}$ test at $100^{\circ} \mathrm{C}$ a $3.2 \mathrm{wt} \%$ titanium alloy had a weight-loss rate of $0.2 \mathrm{mg} / \mathrm{cm}^{2}-\mathrm{hr}$, but at $178^{\circ} \mathrm{C}$ the alloy cracked and corroded badly.

M2

\section{OXIDATION OF URANIUM ALLOYS IN CARBON} DIOXIDE AND AIR. J. E. Antill and K. A. Peakall. J. Less-Common Metals, 3: 239-246 (June 1961 ).

Weight gain-time curves were obtained for alloys of uranium containing up to $7.3 \%$ silicon, $10 \%$ titanium, $5 \%$ vanadium, $10 \%$ zirconium, $15 \%$ molybdenum, $10 \%$ niobium, and $1 \%$ copper in carbon dioxide at $500-1000^{\circ} \mathrm{C}$ and in air at $500^{\circ} \mathrm{C}$. Additions of titanium, molybdenum, niobium, and copper reduced the attack by carbon dioxide at $680-1000^{\circ} \mathrm{C}$ by factors up to 500 . None of the elements was found to be markedly beneficial in carbon dioxide at $500^{\circ} \mathrm{C}$ and the silicon alloys had a high rate of attack in carbon dioxide at most temperatures. Additions of molybdenum, titanium, and niobium reduced the attack in air at $500^{\circ} \mathrm{C}$ by factors up to 200 .
M3

IGNITION OF BINARY ALLOYS OF URANIUM.

J. G. Schnizlein, L. Baker, Jr., and J. D. Bingle, J. Nucl. Mater., 20: 39-47 (July 1966).

A study is reported of the effect of alloying additions on the ignition of $U$. The experiments were performed by placing nominal $8.5-\mathrm{mm}$ alloy cubes in a flowing oxidizing atmosphere within a furnace whose temperature was increasing at the rate of $10^{\circ} \mathrm{C} / \mathrm{min}$. Differences in the sample temperature-time curves were noted for binary $U$ alloys containing $0.5,1$, and 2 at.\% at 24 different elements. Results were interpreted in terms of the effect of the alloying addition on the previously demonstrated transition of the oxide at 400 to $500^{\circ} \mathrm{C}$.

M4

OXIDATION OF URANIUM-TITANIUM ALLOYS IN CARBON DIOXIDE AT $450^{\circ}$ C. M. E. Gerrish, J. J. Stobbs. J. Inst. Metals, 95: 284-286 (Sept. 1967).

Alloy samples containing $0.9,3.6,8.1$, and 18.8 at.\% Ti were annealed at $1000^{\circ} \mathrm{C}$, and oxidation kinetics were measured on a microbalance at $450^{\circ} \mathrm{C}$ in $\mathrm{CO}_{2}$ at $100 \mathrm{~mm}$ pressure. The early stages of oxidation were also studied metallographically. The results, which are presented graphically, show that although the oxidation rate of $\mathrm{U}_{2} \mathrm{Ti}$ is low, the presence of $\mathrm{U}_{2} \mathrm{Ti}$ precipitates in dilute alloys containing greater than about 4 at.\% $\mathrm{Ti}$ leads to a significant increase in the rate compared with that of $U$. Localized oxidation occurs at the precipitate/matrix interface, and the rate increases with $\mathrm{Ti}$ content up to at least 19 at.\%.

M5

EFFECTS OF THE ENVIRONMENT ON THE CRACKING BEHAVIOR OF SELECTED URANIUM ALLOYS. N. J. Magnani. Report SC-R-722661 . (1971). 9p.

From International Corrosion Conference; St. Louis, Mo.; (20 Mar. 1972).

The uranium-base alloys U-7.5 wt $\% \mathrm{Nb}-2.5 \mathrm{wt} \% \mathrm{Zr}$, U-4.5 wt $\% \mathrm{Nb}, \mathrm{U}-10 \mathrm{wt} \% \mathrm{Mo}$, and U-0.5 wt $\%$ Ti were tested in several environments to determine their susceptibility to stress corrosion cracking. The test environments ranged from $<10 \% \mathrm{RH}$ air and $100 \% \mathrm{RH}$ air for U-10 wt $\%$ Mo to $<10 \% \mathrm{RH}$ air, $100 \% \mathrm{RH}$ air, pure gases $\left(\mathrm{O}_{2}\right.$, $\mathrm{N}_{2}, \mathrm{CO}_{2}, \mathrm{H}_{2}$ ), and aqueous solutions ranging from $<2$ to $500 \mathrm{ppm} \mathrm{Cl}{ }^{-}$for $\mathrm{U}-7.5 \mathrm{wt} \% \mathrm{Nb}-2.5 \mathrm{wt} \% \mathrm{Zr}$. The results showed that all the alloys stress corrosion cracked in laboratory air. Aqueous solutions containing chloride ions were more hostile to the alloys tested than laboratory air. From the results it is believed that transgranular cracking which has been observed in uranium alloys is caused by a two-stage mechanical stress corrosion cracking mechanism involving either oxidation at the crack tip and then rupture of the film or the base material below the film, or the adsorption of oxygen at the crack tip and then rupture of the weakened matrix material. 
N

\section{FUEL ELEMENT APPLICATIONS AND IRRADIATION EFFECTS}

N1

VOLUME INCREASES IN FISSILE MATERIALS ON NEUTRON IRRADIATION AND THE EFFECTS OF THERMOFLUCTUATIONS. G. W. Greenwood. Report AERE-R2864. Jan. 1959.

A $2.5 \mathrm{wt} \%$ titanium-uranium alloy, irradiated at $550^{\circ} \mathrm{C}$ to 0.68 percent burn-up, showed a volume increase of more than 100 percent.

N2

IMPROVEMENTS IN OR RELATING TO URANIUM ALLOY FUEL ELEMENTS FOR NUCLEAR

REACTORS. R. A. U. Huddle and D. R. V. Silvester (to United Kingdom Atomic Energy Authority). British Patent 823,392. Nov. 11, 1959.

Ten $U$ fuel alloys are described and compared with pure $\mathrm{U}$ in their oxidizibility by $\mathrm{CO}_{2}$ at $500^{\circ} \mathrm{C}$. The compositions were (in wt\%) $1 \% \mathrm{Zr}, 3 \% \mathrm{Zr}, 1 \% \mathrm{~V}, 1 \% \mathrm{Nb}, 1 \% \mathrm{Ta}$, $1 \% \mathrm{Fe}, 1 / 2 \% \mathrm{Cu}, 1 \% \mathrm{Cu}$, and $1 \% \mathrm{Zr}-0.25 \% \mathrm{Cu}$. Pure U was oxidized 3.8 to 6.7 times as much as the alloys.

N3

PRESENT TRENDS IN NUCLEAR FUELS. C. Bella (CAMEN, Leghorn). Energia nucleare (Milan), 8: 135148 (Feb. 1961). (In Italian).

Nuclear fuel elements are considered which are able to withstand temperatures much higher than those currently reached in reactors. Uranium alloys offer possibilities for increased reactor temperatures. However, for nuclear kwh to become competitive with power from conventional sources (operating temperatures of 800 to $1500^{\circ} \mathrm{C}$ are necessary), the most satisfactory prospects are to be found in fuel elements constituted of fissionable ceramic compounds. After reviewing the disadvantages which are common to metallic fuels in general, the possibilities for applications of ceramic fuels are evaluated. The utilization of these compounds as matrices for dispersion fuels is examined.

N4

PHASE TRANSFORMATION AND DISORDERING BY IRRADIATION OF THE COMPOUND $\mathrm{U}_{2} \mathrm{Ti}$. J. Bloch. Compt. Rend. 259: 1343-1346 (Aug. 10, 1964). (In French).

It was established that the intermetallic compound $\mathrm{U}_{2} \mathrm{Ti}$ with ordered hexagonal crystalline structure undergoes, under the effect of fission-particle irradiation, a disordering accompanied by a phase change. The high temperature disordered phase was obtained. This transformation is achieved after $8 \times 10^{16}$ fissions/sec. Anneal restoration was studied and it was established that the restoration occurs continuously.
N5

PHASE CHANGE AND DISORDER PRODUCTION BY IRRADIATION OF $\mathrm{U}_{2}$ Ti. J. Bloch. Bull. Soc. Sci. Bretagne, 39: 141-146 (1964). (In French).

The phase change and disorder production was studied in a $\mathrm{U}-\mathrm{Ti}$ alloy containing 35 at.\% $\mathrm{Ti}$, a composition that yields an alloy consisting essentially of the phase $\mathrm{U}_{2} \mathrm{Ti}$. The samples were exposed to reactor irradiation and a crystallographic analysis was made. The results indicated that in the U-Ti alloy a cubic and a hexagonal phase co-exist. The role of collisions is predominant as they produce the disorder point-by-point. The parameters are altered progressively by the remote stresses created by atoms in a poor position in the lattice.

N6

EFFECTS OF NEUTRON IRRADIATION ON U ${ }_{2} \mathrm{Ti}$. Z. Baran, J. Bazin, J. Bloch, and A. Accary. J. Nucl. Mater.; 38: 67-76 (Jan. 1971). (In French).

The completely ordered hexagonal $\mathrm{U}_{2} \mathrm{Ti}$ phase was submitted to a sequence of neutron irradiations at a temperature of about $100^{\circ} \mathrm{C}$. After each irradiation the $x$-ray diffraction pattern was determined using an $x$-ray diffractometer specially designed for radioactive materials examination. It was found, that the diffraction pattern progressively changed from the one characteristic of the ordered phase to the one corresponding to the cubic disordered phase. Comparing the intensities of the superlattice lines to those of the fundamental lines of the phase, the degree of order was measured as a 0 value for a flux of $10^{18} \mathrm{n} / \mathrm{cm}^{2}$. This experimental result is interpreted assuming that every elementary fission causes the complete disordering in a small volume of the ordered matrix. The value of this volume is calculated and equals $3.2 \times 10^{-17} \mathrm{~cm}^{3}$. This volume consists roughly of $1.7 \times 10^{6}$ atoms.

N7

STUDY BY COMPUTER SIMULATION OF THE EFFECT OF NEUTRON IRRADIATION ON AN ORDERED SOLID SOLUTION. Z. Baran. Phys. Status Solidi (a); 8: No. 1, 53-60 (16 Nov. 1971). (In French).

To verify a previous hypothesis, according to which the neutron irradiation of an ordered alloy $\mathrm{U}_{2} \mathrm{Ti}$ introduces a substitution-type disorder, the process of x-ray diffraction by a one-dimensional crystal was simulated by a computer. The intensities of the fundamental and substructure diffraction peaks were computed as functions of the number of fission spikes in the originally ordered alloy. The randomly distributed fission spikes are supposed to have a completely disordered substitutional structure. From the intensities, the long-range-order parameter is deduced as a function of concentration of spikes and compared with experimental results. The good fit of the theoretical curve with experimental data confirms the adopted fission-spike model. 


\section{$P$ \\ PROGRESS REPORTS AND NEWSLETTERS}

PA

Argonne National Lab., Lemont, Illinois

PA 1

METALLURGY DIVISION REPORT FOR JANUARY, FEBRUARY, AND MARCH 1949. Report ANL-4316. Mar. 31, 1949. Decl. with deletions Mar. 11, 1957. 96p. Preferred orientation in thermally cycled U-Ti alloys is discussed.

PA2

METALLURGY DIVISION ANNUAL REPORT FOR 1958. Report ANL-5975. Mar. 1959. 125p.

The development of water-corrosion-resistant U-Ti alloys is described.

PA3

ANNUAL REPORT FOR 1960, METALLURGY

DIVISION. Report ANL-6330. 273p.

Corrosion rates of $\mathrm{U}-3 \mathrm{wt} \% \mathrm{Ti}$ with small amounts of $\mathrm{Nb}$ and $\mathrm{Ru}$ are presented for times up to 234 days in water.

PA4

REACTOR DEVELOPMENT PROGRAM PROGRESS REPORT, MARCH 1965. Report ANL-7028. Apr. 20, 1965. 93p.

The effect of temperatures on mechanical properties of $\mathrm{U}-\mathrm{Ti}$ alloys is reported.

PB

Battelle Memorial Inst., Columbus, Ohio

PB 1

METALLURGY OF TUBALLOY(URANIUM). Progress Report CT-2700. Feb. 1, 1945. Decl. Feb. 19, 1957. $50 \mathrm{p}$.

Phase changes in U-Nb and Ti-U alloys were studied. Data are included on corrosion testing of $\mathrm{T} i-\mathrm{U}$ alloys in $\mathrm{H}_{2} \mathrm{O}$.

PB2

PROGRESS RELATING TO CIVILIAN APPLICATIONS DURING NOVEMBER 1955. Russell W. Dayton and Clyde R. Tipton, Jr. Report BMI-1057. Dec. 1, 1955. Decl. with deletions Mar, 12, 1957. 70p.

Studies are presented on the thermal conductivity of U-Ti alloys. Studies on the hardness of U-Ti alloys versus cooling rate, and on the hot hardness of as-rolled U-Ti alloys are also presented.
PB3

PROGRESS RELATING TO CIVILIAN APPLICATIONS DURING DECEMBER 1955. Russell W. Dayton and Clyde R. Tipton, Jr. Report BMI-1062. Jan. 1, 1956. Decl. with deletions Mar. 6, 1958. 82p.

Progress is reported on the physical and mechanical properties of U-Ti alloys.

PB4

PROGRESS RELATING TO CIVILIAN APPLICATIONS

DURING FEBRUARY 1956. Russell W. Dayton and Clyde R. Tipton, Jr. Report BMI-1076. Mar. 1, 1956. Decl. with deletions Feb. 13, 1957. 79p.

The preparation of U-Ti alloys is discussed.

PB 5

PROGRESS RELATING TO CIVILIAN APPLICATIONS DURING MARCH 1956. Russell W. Dayton and Clyde R. Tipton, Jr. Report BMI-1080. Apr. 2, 1956. Decl. with deletions Feb. 13, 1957. 87p.

Results of quenching and aging U-Ti alloys are presented.

PB6

PROGRESS RELATING TO CIVILIAN APPLICATIONS DURING MAY 1956. Russell W. Dayton and Clyde R. Tipton, Jr. Report BMI-1094. June 1, 1956. Decl. with deletions Feb. 13, 1957. 86p.

Studies were continued on the heat treatment of U-Ti alloys.

PB7

PROGRESS RELATING TO CIVILIAN APPLICATIONS DURING MAY 1957. Russel W. Dayton and Clyde R. Tipton, Jr. Report BMI-1189. June 1, 1957. Decl. Feb. 4, 1960. 59p.

Tensile test data are presented for martensitic U-Ti alloys.

PC

Canadian Dept. of Mines and Technical Surveys, Ottawa, Canada

PC 1

URANIUM ALLOY DEVELOPMENT FOR NONNUClEAR APPliCation. Progress Report No. 3. H. M. Skelly, C. F. Dixon, and N. S. Spence. Report AED-CONF-65-277-5. 24p. (CONF-650841-2).

ORAU. Gmelin. From Conference of Metallurgist, Ottawa.

Casting procedures are given for $\mathrm{U}-0.5 \% \mathrm{Ti}$, and $\mathrm{U}-2 \%$ $\mathrm{Ti}$ alloys. The castings were assessed for quality by chemical and $\mathrm{x}$-ray fluorescence analyses, gamma radiography, and microexamination. The alloys were examined in the as-cast and heat-treated condition. Hardness values as well as compressive and tensile strength values are given. 
RFP-2005

PN

URANIUM ALLOY NEWSLETTER. Division of Research, USAEC

PN1

URANIUM ALLOY NEWSLETTER NO. 8. David $W$. Lillie, Ed. Report WASH-1 55. Aug. 1954. Decl. Oct. 7, 1959. 66p.

Dilute binary alloys of uranium including U-Ti were produced by co-reduction. Corrosion of U-Ti alloys by boiling water was investigated.

\section{PN2}

URANIUM ALLOY NEWSLETTER NO. 9. J. Fred White, Ed. Report WASH-156. Nov. 1954. Decl. with deletions Mar. 5, 1957. 42p.

Tensile tests performed on a very low U-Ti alloy at Battelle Memorial Inst. showed no improvements in tensile properties over unalloyed uranium. At Mallinckrodt Chemical Works U-Ti alloys were produced by co-reduction and cast.

PN3

UR ANIUM ALLOY NEWSLETTER NO. 14. Edward Epremian, Ed. Report WASH-296. Mar. 1956. Decl. Mar. 6, 1957. 62p.

Mechanical properties of U-Ti alloys are discussed.

PN4

URANIUM ALLOY NEWSLETTER. Edward Epremian, Ed. Report WASH-298. Sept 1956. Decl. with deletions Mar. 5, 1957. 36p.

Some corrosion and tensile property data on U-Ti alloys is presented.

\section{PN5}

URANIUM ALLOY NEWSLETTER. Edward Epremian, Ed. Report WASH-700. Nov. 1956. Decl. Mar 30, 1960. 25p.
At Argonne National Lab., the effect of heat treatment on microstructure is being studied as part of the effort to understand the effect of alloying on corrosion resistance in $\mathrm{Ti}-\mathrm{U}$ alloys. At Battelle Memorial Inst., phase relationship studies between the intermediate delta phase of the U-Mo and U-Ti systems were conducted.
PR

REACTIVE METALS, INC., Ashtabula, Ohio

PR 1

SEMI-ANNUAL PROGRESS SUMMARY (ON METAL FABRICATION), JULY-DECEMBER 1967. Report RMI-10. Feb. 12, 1968. 53p.

Operational procedures have been defined for swaging uranium wire as small as 0.032 -in. diameter from both unalloyed and U-base $0.75 \%$ titanium stock.

PS

NATIONAL BUREAU OF STANDARDS, Washington, D. C.

PS1

QUARTERLY PROGRESS REPORT FOR APRIL, MAY, AND JUNE 1953. Report NBS-D-124. Sept. 1953. Decl. Mar. 8, 1957. 59p.

Phase studies are presented on $\mathrm{U}-\mathrm{Ag}, \mathrm{U}-\mathrm{Ti}$, and $\mathrm{U}-\mathrm{Au}$ alloys. 


\section{ORGANIZATIONAL REPORT SYMBOLS}

\begin{tabular}{|c|c|c|c|}
\hline Symbol & Title of Organization & Symbol & Title of Organization \\
\hline $\mathrm{A} / \mathrm{CONF} 15 / \mathrm{P} /($ no.) & $\begin{array}{l}\text { United Nations-International } \\
\text { Conference on the Peaceful Uses of } \\
\text { Atomic Energy, } 1958 \text {. }\end{array}$ & LA & $\begin{array}{l}\text { Los Alamos Scientific Laboratory, } \\
\text { Los Alamos, New Mexico. }\end{array}$ \\
\hline ACED & $\begin{array}{l}\text { U. S. Atomic Energy Commission } \\
\text { Declassified Document. }\end{array}$ & NBS & $\begin{array}{l}\text { National Bureau of Standards, } \\
\text { Washington, District of Columbia. }\end{array}$ \\
\hline AECU & $\begin{array}{l}\text { Division of Technical Information } \\
\text { Extension, USAEC. }\end{array}$ & NP & $\begin{array}{l}\text { Division of Technical Information } \\
\text { Extension, USAEC. }\end{array}$ \\
\hline AERE & $\begin{array}{l}\text { Atomic Energy Research Establish- } \\
\text { ment, Harwell, Berks, Great Britan. }\end{array}$ & ORNL & $\begin{array}{l}\text { Oak Ridge National Laboratory, } \\
\text { Oak Ridge, Tennessee. }\end{array}$ \\
\hline ANL & $\begin{array}{l}\text { Argonne National Laboratory, } \\
\text { Argonne, Illinois. }\end{array}$ & PG & $\begin{array}{l}\text { United Kingdom Atomic Energy } \\
\text { Authority. Production Group, } \\
\text { Risley, Lancs, England. }\end{array}$ \\
\hline BMI & $\begin{array}{l}\text { Battelle Memorial Institute, Columbus, } \\
\text { Ohio. }\end{array}$ & REMI & $\begin{array}{l}\text { Reactive Metals, Incorporated, } \\
\text { Ashtabula, Ohio. }\end{array}$ \\
\hline CEA & $\begin{array}{l}\text { Commissariat a-l'Energic Atomique, } \\
\text { Paris, France. }\end{array}$ & RFP & $\begin{array}{l}\text { Dow Chemical U.S.A., Rocky Flats } \\
\text { Plant, Denver, Colorado. }\end{array}$ \\
\hline CNEN & $\begin{array}{l}\text { Comitato Nazionale per l'Energia } \\
\text { Nucleare, Rome, Italy. }\end{array}$ & $\mathrm{RT} /$ & $\begin{array}{l}\text { Comitato Nazionale per l'Energie } \\
\text { Nucleare, Rome, Italy. }\end{array}$ \\
\hline CONF & $\begin{array}{l}\text { Serial number assigned to conference } \\
\text { cataloged by the USAEC Division of } \\
\text { Technical Information Extension. }\end{array}$ & SL & $\begin{array}{l}\text { Sandia Laboratory, Albuquerque, } \\
\text { New Mexico. }\end{array}$ \\
\hline DMIC & $\begin{array}{l}\text { Defense Metals Information Center, } \\
\text { Battelle Memorial Institute, Columbus, }\end{array}$ & TID & $\begin{array}{l}\text { Division Technical Information } \\
\text { Extension, USAEC. }\end{array}$ \\
\hline & Ohio. & UCID & $\begin{array}{l}\text { University of California at Berkeley, } \\
\text { Radiation Laboratory, Berkeley, } \\
\text { California. }\end{array}$ \\
\hline HW & $\begin{array}{l}\text { General Electric Company, Hanford } \\
\text { Atomic Products Operation, Richland, } \\
\text { Washington. }\end{array}$ & UCRL & $\begin{array}{l}\text { University of California, Lawrence } \\
\text { Radiation Laboratory, Livermore, } \\
\text { California. }\end{array}$ \\
\hline IGO-AM/S & $\begin{array}{l}\text { United Kingdom Atomic Energy } \\
\text { Authority. Industrial Group, } \\
\text { Springfields Work, Springfields, Lancs, } \\
\text { England. }\end{array}$ & $\mathrm{Y}$ & $\begin{array}{l}\text { Union Carbide Corporation, Nuclear } \\
\text { Division, Y-12 Plant, Oak Ridge } \\
\text { Tennessee. }\end{array}$ \\
\hline KAPL & $\begin{array}{l}\text { Knolls Atomic Power Laboratory, } \\
\text { Schenectady, New York. }\end{array}$ & ZFK & $\begin{array}{l}\text { Zentralinstitut fur Kernphysik, } \\
\text { Dresden, Germany. }\end{array}$ \\
\hline
\end{tabular}


RFP-2005

\section{SUBJECT INDEX AND ABSTRACT NUMBERS}

A

Alloying
Alloying By Co-reduction

A 7, B3, B4

A4, B 2

B

Beta Treatment

Casting

Chemical Analysis

Chemical Purity

Compatability

Compressive Properties

Constitutional Diagrams

Corrosion Resistance

Cracking

Creep Strength

Crystallography

Density

Diffusion

Dimensional Stability

Fabrication

Fuel Elements

Fuel Element Fabrication

Grain Size

Habit Planes

Hardness

Hardness (Hot)

Heat Capacity

Heat Treating

Ignition

Impact Strengths

Impurity Effects

Irradiation Effects

$$
\text { A 2, F 5, L } 2
$$

C

$$
\text { B 1, PC1 }
$$

$\mathrm{C} 1, \mathrm{C} 2, \mathrm{C} 3, \mathrm{C} 4, \mathrm{C} 5, \mathrm{C} 6$

A7

G5, G6

$\mathrm{PC} 1$

A3, A4, A6, E1, E 2, E3, E4, E5, E6, E7, E8, E9, G4

A1, A3, A4, A5, A6, D6, D7, M1, M2, M4, PA 2, PA3, PB1, PN 1, PN4, PN5

D4

A4, D 1, D3, L3

$\mathrm{E} 6, \mathrm{H} 1, \mathrm{H} 2, \mathrm{H} 3, \mathrm{H} 5, \mathrm{I} 1, \mathrm{I} 2, \mathrm{I} 3$, N4, N5, N6, N7

\section{D}

A5

G1, G2, G3, G4, G5, G6, G7

(See Thermal Stability \& Residual Stress)

F

A4, A 7, B 1, E3, PR 1

N2, N3

Al

G

$$
\text { A2, F4, F6, L2 }
$$

H

F7, H5, I3

A2, A4, A5, F1, F2, F3, H2, $\mathrm{J} 1, \mathrm{PC} 1$

PB2

L5, L6

A5, A6, D4, D5, D6, D7, F1, F2, PB5, PB6

\section{I}

M3

A3, A4

D8

N1, N4, N5, N6, N7
K

Kirkendall Effect

G1, G2, G3

L

Lattice Parameters

(See Crystallography) A8, G6

Literature Surveys

M

Machinability

A7

Martensitic Phases

Mechanical Properties

Metallography

Microstructure

Order-Disorder

Transformations

Oxidation

Patents

D4, D6, F1, F3, F5, F6, G7, $\mathrm{H} 1, \mathrm{H} 2, \mathrm{H} 3, \mathrm{H} 4, \mathrm{H} 5$

A2, A5, A6, B5, D3, D5, D7, E9, F1, PA4, PB3, PN3

A4, J2

F2, F4, J1, PN5

0

N4, N5, N6, N7

M2, M3, M4

P

A1, N2

R

Recrystallization

Residual Stresses

H5

$\mathrm{H} 3$

$\mathrm{S}$

Stress Corrosion

Swaging

D7, M5

PR1

T

Tensile Properties

Texture

A3, A4, D 2, D6, D8, PB7, PC1, PN4

PA 1

Thermal Condúctivity

A 2, PB2

Thermal Expansion

$\mathrm{A} 2, \mathrm{~L} 1$

Thermal Stability

A6, D4, H3, L2, L3, PA 1

Thermodynamic Properties

Toxicity

L4, L5, L6

Transformation Kinetics

A7

(see also Constitution, heat treating)

A4, F1, F2, F3, F4, F5, F6, F7, H1, H2, H5, I3, L1, PB 1 , PN5, PS 1

V

Vibrational Spectrum

L5, L6

W

Weldability

A4, B5

$\mathrm{Y}$

Yield Surface 


\section{AUTHOR INDEX AND ABSTRACT NUMBERS}

A

Accary, A.

Adda, Y.

Ammons, A. M.

Anagnostidis, $\mathrm{M}$.

Antill, J. E.

Avery, J. G.

Bacon, A.

Baker, L.

Baran, Z.

Baschwitz, R.

Bauer, A. A.

Bazin, J.

Bella, C.

Beyeler, M.

Bingle, J. D.

Bloch, J.

Boudouresques, B.

Boulger, F. W.

Burke, J.

Buzzard, R. W.

Calais, D.

Chernoplekov, N. A.

Chubb, W.

Colombie, $\mathrm{M}$.

Cornet, J. A.

Cornet, J. F.

Dickerson, R. F. Douglass, D. L.

Draley, J. E.

Dunworth, R. J.

Eddy, N. S.

Englander, M.

Federer, J. I.

Fickle, D. P.

Fizzotti, C.

Foure, M.

Franceschetti, G.

Frost, P. D.
E

N6
G1, G2, G3, G4
F7
H4
M2
D8

B

C3
M3
N6, N7
H4, H5
E6
N6
N3
G4
M3
N4, N5, N6
D3
E1, E3
I3
E2

C

G7

L5

A2

$\mathrm{H} 4$, H5

G7

G7

D

J2

F1, F2, H3

M1

B1

D1

D3

F

D5

E2

A6, F 6

H5

F6

D2
G

Gerrish, M. E.

Green, E. A.

Greenwood, G. W.

Grigorovich, V. K.

M4

B5

N1

L3

H

Harding, A. G.

Holinka, M.

Howlett, B. W.

Huber, O. J.

Huddle, R. A. U.

$\mathrm{H} 1, \mathrm{H} 2$

G6

E7

D2

N2

Ivanov, O. S.

D4, E9, F 5

Jaffee, R. I.

Jepson, M. D.

Johnson, I.

E8

F4

L4

K

Karnikova, E.

Keeler, J. R.

Kehoe, R. D.

Kinsey, H. V.

Kirianenko, A.

Klebanow, H. L.

Knapton, A. G.

Knight, C.

Kutaitsev, V. I.

G6

A 1

F4

B4

G4

D1

E5, E7, I1

$\mathrm{H} 2$

L5

L

Languille, A.

Linard, M.

Liss, R. B.

G7

D6

E2

M

Macherey, R. E.

Magnani, N. J.

Makarov, Ye.S.

Makepeace, C. E.

Manning, G. K.

Marsh, L. L.

Masarik, V.

Masperoni, A.

Maurice, F.

Maykuth, D. J.

McWhirter, J. W.
B 1

M5

12

B3

F 1

F1, F2

G6

A6

G4

E8

M1 
RFP-2005

Milner, G. W. C.

Murphy, D. J.

Nichols, R, W.

Ogden, H. R.

Panova, G. Kh.

Peakall, K. A.

Phennah, P. J.

Philibert, J.

Rémy, C.

Robinson, H. A.

Roellig, $\mathrm{H}$.

Rough, F. A.

Saller, H. A.

Samoilov, B. N.

Sandstrom, D. J.
$\mathbf{N}$

$\mathrm{C} 1, \mathrm{C} 2, \mathrm{C} 3$

A3, F3

F4

o

E8

$\mathbf{P}$

L5, L6

M2

$\mathrm{C} 1, \mathrm{C} 2$

G1, G2, G3

$\mathbf{R}$

G7

D2

G5

A2, E4, E6

S

A1, A2, D1, E4, J2

L5, L6

D7
Schnizlein, J. G.

Semenchenkov, A. T.

Seybolt, A. U.

Silcock, J. M.

Silvester, D. R. V.

Sladkova, N. E.

Slattery, G. F.

Stacy, J. T.

Stobbs, J. J.

$\mathrm{T}$

Tardif, H. P.

Tomlinson, R. D.

$\mathrm{U}$

Udy, M. C.

W

Waldron, M. B.

White, D. W.

Wilkinson, W. D.

Wyman, L. L.

Z

Zegler, S. T.

Zemlyanov, M. G.
A5

13

E1, E3

$\mathrm{H} 1, \mathrm{H} 2$

E1

A4

L1

L2

M3

D4, F5

E1, J1

I3

N2

L3

F4

D1

M4

3

L5 